\title{
CORRIGENDUM
}

\section{STAT4 is a confirmed genetic risk factor for Sjögren's syndrome and could be involved in type 1 interferon pathway signaling}

N Gestermann ${ }^{1}$, A Mekinian ${ }^{1}$, E Comets $^{2}$, P Loiseau ${ }^{3}$, X Puechal ${ }^{4}$, E Hachulla ${ }^{5}$, J-E Gottenberg ${ }^{6}$, $X$ Mariette $^{1,7}$ and C Miceli-Richard ${ }^{1,7}$

Genes and Immunity (2010) 11, 446; doi:10.1038/gene.2010.38

Correction to: Genes and Immunity (2010) 11, 432-438; doi:10.1038/gene.2010.29

Since the publication of the above article, the authors have noticed that affiliation 7 was incorrect.
The incorrect affiliation was Pharmacologie, Hôpital Bicêtre, Assistance Publique-Hôpitaux de Paris (AP-HP), Le Kremlin Bicêtre, France.

This has now been removed. 